\title{
INSTRUMENTAL THEATER IN THE WORKS OF MAURICIO KAGEL, GEORGES APERGHIS AND HEINER GOEBBELS*
}

\author{
UDC 78.071.1:792
}

\author{
Neda Nikolić \\ University of Niš, Faculty of Arts in Niš, Republic of Serbia
}

\begin{abstract}
The characteristic of the genre of instrumental theater is both the symbiosis of music and theater, as well as the fact that composers are also directors, while musicians have the opportunity, in addition to their expected roles, to be in contact with other arts. The specificity of the genre is that it is displaced from the original environment and replaced in a new context, which allows the performers to interact with each other, as well as to be in close communication with the audience. The impact of the audience on the performance contributes to the final design of the piece, which is why its engagement is of utmost importance to the genre. Composers such as Mauricio Kagel, Georges Aperghis and Heiner Goebbels made the greatest contribution to this genre.
\end{abstract}

Key words: instrumental theatre, Mauricio Kagel, Georges Aperghis, Heiner Gobbels, symbiosis

\section{INTRODUCTION}

"If one looks at contemporary trends (...), the basic aspiration is indicated: the abolition of traditional genre boundaries and typologies. The purest example of this boundary abolition can be best observed in the new musical theater". "It is not a stylistically fixed form of theater that exists among others, but it represents the application of musical thinking to theater (...)." (Šuvaković 2018, 11-12)

The symbiosis of the musical and theatrical arts characteristic of the genre of instrumental theater is reflected in the fact that composers are also directors, while musicians have the opportunity, in addition to their expected roles, to be connected to the other arts. The unique aspect of the genre is its displacement from the original environment

Received February 24, 2020 / Accepted March 24, 2020

Corresponding author: Neda Nikolić

University of Niš, Faculty of Arts

E-mail: nikolic.neda95@gmail.com

* The work was realized under the mentorship of dr Ivan Brkljačić, in the course of the Music theory, in the first year of PhD studies, academic 2018/2019.

${ }^{1}$ The term new musical theater is closely related to the term instrumental theater, and they are synonyms. 
and placement in a new context, allowing the performers to interact with one another, as well as maintaining their close connection with the audience. The engagement of the audience is of paramount value for the genres. Therefore, their engagement in the performance has a significant contribution to the final design of the piece.

Each work is a process that is generated by the thorough preparation of the composer, the study of the matter that precedes the creation of the work with the tendency for each segment of the composition to be organized. On the other hand, there is indulgence of some elements to the random chance through which the composers incorporate a surprising impact that provides a dose of spontaneity to the works created within the instrumental theater.

The characteristics of instrumental theater will be examined and exemplified through the works of Mauricio Kagel's Pas de cinq, Georges Aperghis's Sept crimes de l'amour, and Heiner Goebbels's Surrogate. Observing the protagonists on stage, their behavior, gestures, movement, analyzing the contexts in which the compositions were created as well as the symbolism and the message of their work are elements that will be specifically examined to gain insight into the very concept of instrumental theater.

Essentially, music and theatre art remain undifferentiated, as musicians are not forced to step out of their role as performers. Musicians in this particular genre have satirical and ironic means of expression within the framework of their musical discourse, in order to paint everyday life, and they manage to shift the theatre from its original environment. These are some main characteristics of Kagel's instrumental theater which will be noted and discussed in this study, through the examination of the composition Pas de cinq.

Apart from the aforementioned composition, the analysis of Georges Aperghis' work The Seven Crimes of Love, represents the rejection of the hierarchy between the visual and musical elements, which is complemented with simultaneous consideration of the meanings brought through verbal expression. Combining acting and music with other art forms allows the composer's broad and open understanding of the concept of this and other works. All of Aperghis's expressive means are intended to depict the state of society through the use of a wide range of symbols.

In addition to these two compositions, Goebbels' work Surrogate will also be thoroughly discussed throughout this study. The synthesis of various arts, evident in Surrogate, is arguably inspired by Wagner's 'gezamtkuntstverk'. Eclecticism, reflecting the state of society and the awkwardness of life are characteristic aspects of Surrogate, thus linking this work to the aforementioned compositions selected as analytical samples. Their characteristics expressed in the field of instrumental theater will be the main focus in the core part of this study.

\section{INSTRUMENTAL THEATRE GENRE}

The origin of instrumental theater dates back to ancient Greece and has evolved to this day. The interpretation of this term is diverse and it can be seen through the various interpretations proposed by different theorists in their attempt to define this genre. According to Mirjana Veselinovic-Hofman, "musical theater is established when music is not only the result of composing on a text, a means of presenting a dramatic flow, but also when the music itself is a dramatic flow, and at the same time, that dramatic flow itself is music." Hans Peter Jan believes that "musical theater implies simultaneity of work processes on the same object". Ivan Brkljačić, however, explains that "instrumental 
theater (...) is seen as a theatrical form in which music is a dramatic flow in its content, and various instruments, as well as the performers who play them, depict the characters of that dramatic act." (Brkljačić 2011, 2-3)

"In the 20th century through the works of Stravinsky (Igor Fyodorovich Stravinsky), Satie (Eric Alfred Leslie Satie), Schoenberg (Arnold Schoenberg), Milhaud (Darius Milhaud), Stockhausen (Karlheinz Stockhausen), Cage (John Milton Cage Jr.) and others, musical theater has expanded, winning over the field of instrumental theater, a special form of musical theater that can be most directly traced through the opus of Mauricio Kagel", whose work is, among other things, the subject of this paper. (Brkljačić $2011,2)$ As the twentieth century progressed, this genre gained popularity, and this was indicated by the fact that composers and ensembles from around the world were increasingly active in the realm of instrumental theater (Conlon Nancarrow, Bushra ElTurk, ensemble Themus from Sweden, Irinel Anghel).

“Terminology such as 'instrumental theater' or azione theatrale ('theater action') suggests that there can be a musical theater consisting of only instrumentalists or that instrumentalists can be actors in their own musical dramas." (Salzman and Desi 2008, 94) Consequently, the theatrical and musical art cannot be separated, as the acoustic and visual components are organically linked and form an unbreakable bond within the instrumental theater.

"This genre strives to rediscover what has been lost in Western classical music: the visual and kinetic nature of performance, the physicality of music-making, the bodily presence of the performers, the three-dimensional space of the stage, and the spectacle of stage events." (Heile 2006, 37) All this opens the space for multiple and different ways of reading and interpreting a piece by an audience.

No matter how different all the definitions of the aforementioned authors are, they are at the same time similar. Through their observations and through attempts to define the genre of instrumental theater more closely, the obvious influence of the concept of theater on the conception of music (and vice versa) is inevitable. In addition, the aim of this genre is to interact with the audience and inspire the performers to shape the work through their active involvement, thus further enriching the musical art.

\section{MAURICIO KAGEL, COMPOSER OF INSTRUMENTAL THEATRE}

"Under the direct influence of Cage, Boulez (Pierre Boulez) and Stockhausen, Mauricio Kagel created the first compositions in the Cologne studio in 1960 that could be classified as instrumental theater, such as Sonant and Sur scenes." (Brkljačić 2011, 5) Therefore, Kagel could be considered a founder of instrumental theater, providing significant contribution of great importance to music and its development in the twentieth century.

The constant permeation of the performing and musical arts, which is a major feature of the genre, could be characterized as "the theatrical quality of any performance of music." Accordingly, "at the expense of the sonic result, it can become difficult to decide whether the players are simply musicians or actors who play musicians, so that the performance becomes fictionalized, like diegetic ${ }^{2}$ music in film or stage music in the theater." (Heile 2006, 4) This is also compounded by the fact that "the success of Kagel's music theater rests on the

\footnotetext{
${ }^{2}$ Diegetic music in a movie or on a TV program is part of the action and characters can hear it, not just people who are watching the movie or TV program, downloaded from: https://dictionary.cambridge.org/dictionary/english/diegetic, accessed on the 20th of June.
} 
continuum between music-making and theatrical action, and, consequently, on musicians who never actually have to step outside their role as performers." (Heile 2006, 36)

When considering Kagel's entire work, reflections of his relative experience in the film industry, as well as his experience in music and instrumental theater, all contribute to the synthesis of these two arts, their interplay and cooperation, which is a logical outcome. Kagel's achievements represent a departure from tradition, while the focus is on issues of society and culture.

“'Avant-garde' and 'uncompromising', 'theatrical' and 'witty', imagination, originality and humor are the hallmarks of this multimedia artist. Inspired by his inexhaustible drive towards being inventive, Kagel uses a very wide variety of expressive means that, although often satirical and provocative, are always put to the service of musical discourse. He explored a wide range of sounds and experiences in compositions that personified the fine balance along the demarcation points among serial improvisation and the theater of the absurd." 3

Leaving nothing to chance, sketching all the details, participating in every segment of the realization of the work, are the crucial points of Kagel's temperament and attitude towards his compositions. "With him, each piece implies a complete process, ranging from the initial step of the composer's own imagination to actual presence on stage in front of an audience, a process that leaves none of the intermediate phases to chance: the development of an idea, scholarly research in a plethora of fields of human thought, the composition of a highly precise score (down to the smallest technical details), the setting up and organization of human relationships (often highly dramatized) with all those who take part, directly or indirectly, in the realization of the piece, not forgetting effective stage, sound and image production..."4 This approach reflects Kagel's seriousness and intention to awaken consciousness and change the approach of the instrumentalists in performing his compositions and compositions written within this genre. "Because of this, Kagel may be considered one of the great thinkers of the contemporary world through his works of art."

\subsection{Instrumental theatre in Pas de cinq by Mauricio Kagel}

The definition and background of the term Pas de cinq, which means five steps in translation, is "a term used for a basic step pattern of several Elizabethan dances such as the galliard, tourdion and the saltarello. The term was also used synonymously with the term 'galliard'." "The energetic and vigorous cinque pas (or cinque passi) are found in all the 16th-century Italian dance treatises (for example, Fabritio Caroso, etc...)." "7

"Kagel's work Pas de cinq (1965) deals entirely with the choreographed movements of actors on the stage. Five mute players walk in different patterns outlining a pentagon." 8 (Heile 2006, 52-53) This can be seen as a symbol of the number five, which is important to the composer and is reflected in the relation between the five steps (pas de cinq) - and the

\footnotetext{
${ }^{3}$ http://www.washingtonpost.com/wpdyn/content/article/2008/09/19/AR2008091903900_2.html?noredirect=on, accessed on the 17 th of June.

${ }^{4} \mathrm{http}$ ///www.cdmc.asso.fr/en/actualites/saison-cdmc/mauricio-kagel-and-instrumental-theatre, accessed on the 17 th of June.

${ }^{5}$ http://www.cdmc.asso.fr/en/actualites/saison-cdmc/mauricio-kagel-and-instrumental-theatre, accessed on the 17 th of June.

${ }^{6} \mathrm{https}: / /$ musicterms.artopium.com/c/Cinquepas.htm, accessed on the $21 \mathrm{st}$ of June.

${ }^{7}$ https://www.oxfordmusiconline.com/grovemusic/view/10.1093/gmo/9781561592630.001.0001/omo-

9781561592630-e-0000005797, accessed on the 18th of June.

${ }^{8}$ Björn Heile, The Music of Mauricio Kagel (Farnham: Ashgate Publishing Limited, 2006), 52-53.
} 
pentagon - pentagon strips have a minimum length of five meters - five boundaries/caesuras in the musical-dramaturgical flow - five performers.

The performers are dressed in uniforms and their appearance shapes another semantic level in relation to the original one which referred to number five. The pentagon was first approached by the "king" because of the crown he wore, highlighting his bourgeois status in society. The entry of the "citizen" from the middle class is a counterpoint together with the "king" produced by uneven steps on different materials and strokes of the rods. The counterpoint is further developed by the entry of other performers: a middle-aged lady, a man who is artistically-minded (judging by his loose tie) and an old man. In this way, the composer portrays the social pyramid through performers who come from different social strata.

Artists produce certain rhythms with their steps, which are complemented by the use of walking sticks. The rhythmic patterns they perform are predetermined for the steps and for the strokes of the sticks (see Fig. 1).

However, since the length of the steps is not predetermined, it happens that the two performers are walking at irregular lengths in a uniform rhythm and vice versa. In doing so, they create a polyphony of steps, characterized by a variation of timbre, while the stage is covered with different materials, such as wood, metal, styrofoam, plastic, sand, linoleum fabric and so on. "This leads to possibly the closest union of kinetic movement resulting music in Kagel's instrumental theater as closely as possible.” (Heile 2006, 53)

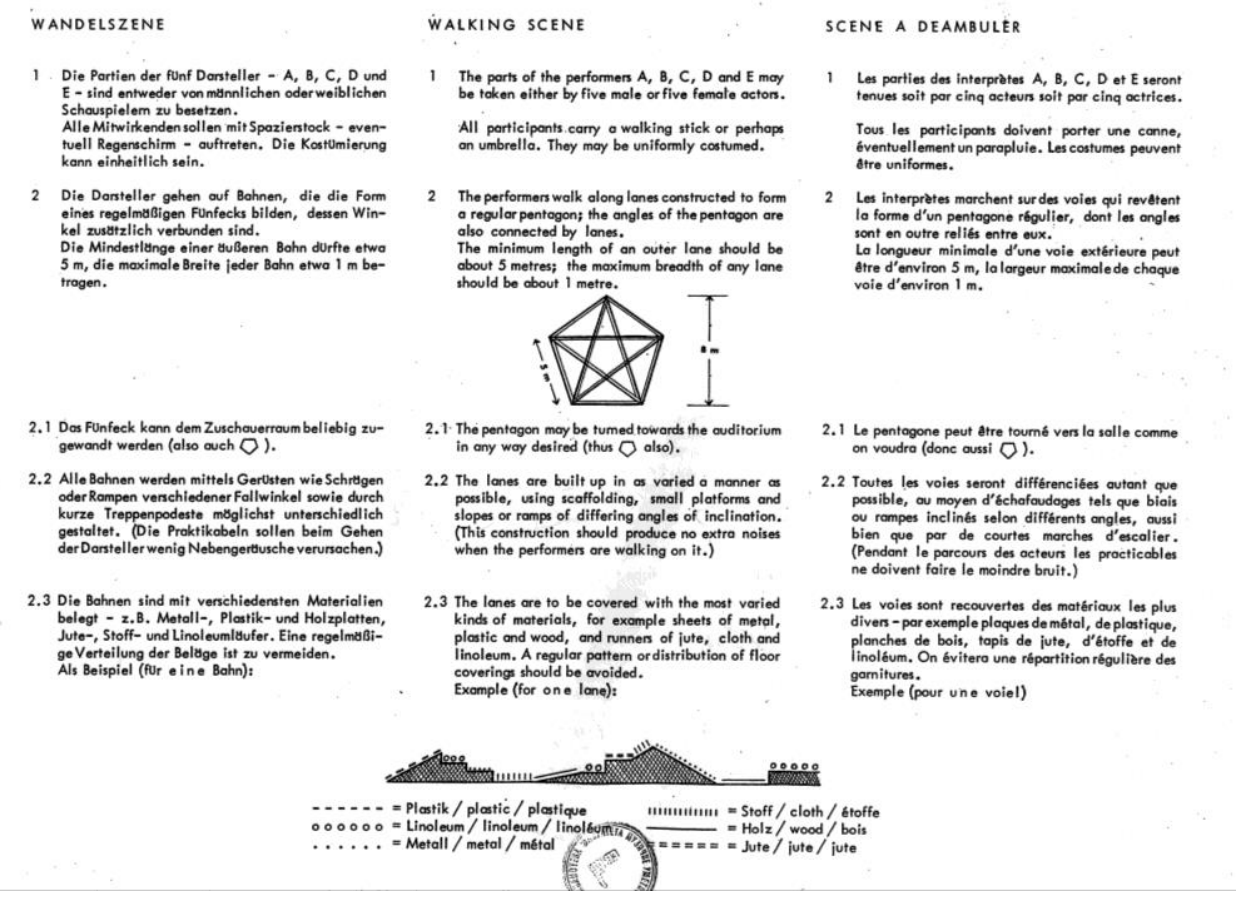

Fig. 1 The homepage of Kagel's Pas de cinq 
"It would be pointless to claim that the musical rhythms are only an accidental result of the stage choreography as to hold that the actors' movements only serve to produce the rhythms (although as a performance option the piece can be played as concert music on percussion instruments)." (Heile 2006, 53) They mimic and make gestures in their performance and the performance of others, and make sounds by pointing to different aspects of difficulty, ridicule or confusion. "Through their gestures, they communicate, interact and form an agreement for further movements and sounds, thus creating a dramaturgical connection between them." "Performers should not only be understood by moonshiners or puppets, and the activities in composition are represented simultaneously thanks to their views, random turns, gallant gestures, et cetera. Their gestures form another semantic level with the help of which they create sounds outside the theater, sounds that come from choreography. This is precisely the composer's way of dealing with theater as a myth about himself from which various "stories" can be distilled.

On the other hand, "the lighting is monochromatic so that the performers could concentrate on the paths they follow. Moving reflectors are not applied, so total lighting is on at the very beginning of the play. Consequently, these stories are without text, but they are composed of movement, light and sound. In this 'instrumental theater', soundproducing gestures are created and transmitted, replacing spoken text but forming a metatext in the sense defined earlier." 10

Within the internal organization of the musical-dramaturgical flow, certain boundaries formed by the performer can be observed (see Fig. 2). Boundaries are always formed by the same process of the composer stopping the performer at certain moments. The piece Pas de cinq begins with the entry of the "King", but also with the successive entry of other performers shortly after. The joint creation of sounds flows and is rounded off by the static of all the performers at one point (minute 2:55), which is why the first boundary in the musical-dramaturgical flow is formed at this place. Following it, the next segment begins with the simultaneous movement of musicians-actors across different pentagon tracks. By stopping the performers again, another boundary was formed (minute 04:15). The polyphony of sounds continues and lasts until one by one the performer begins to slow the flow by stopping in place (minute 05:20). After the caesura, the sound production again forms a counterpoint in which the interruption occurs suddenly (minute 07:16), with the sudden static of the performers. The final segment rounds up the entire musical and dramaturgical flow of this piece. Similar to Haydn's "Farewell Symphony", the same symbolic gesture is staged as one by one the performer exits the pentagon and pauses. The first of these was the artist, then the "king", who is an inversion of the beginning of the piece itself. The old man also symbolizes the end of the piece with his death, so that after the citizen leaves the pentagon, the middle-aged woman encircles the Pas de cinq with a symbolic stroke of the stick into broken pottery. The circular form of the work can be noticed because of the simple texture at its beginning, which, by layering the performance of the performers, complicates it during the piece, in order to reduce the texture to the initial with separate departures of the artist and thus ensure the roundness of the Pas de cinq due to the similar situation at its beginning and at its end.

\footnotetext{
${ }^{9}$ http://www.bbc.co.uk/radio3/cutandsplice/kagel.shtml, accessed on the 21st of June.

${ }^{10}$ Eric Salzman and Thomas Desi, The New Music Theater. Seeing the Voice, Hearing the Body (Oxford: Oxford Uniersity Press, 2008), 324.
} 


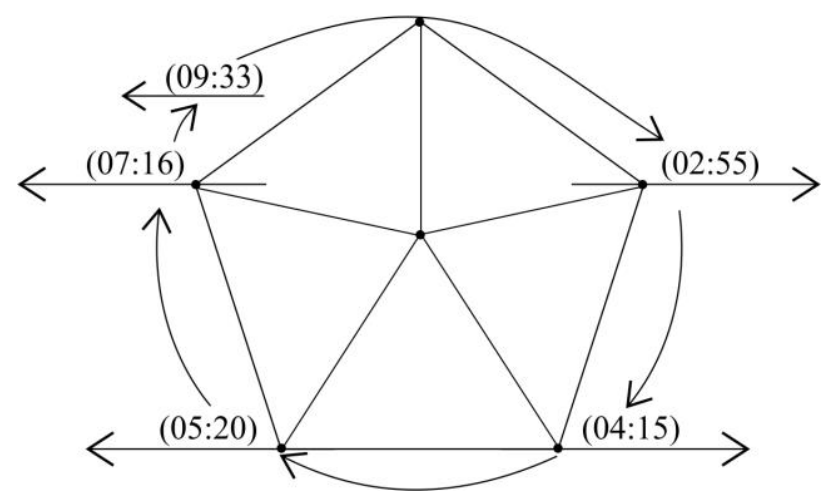

Fig. 2 The boundaries in the musical-dramaturgical flow of Kagel's Pas de cinq shown through the pentagram

By various means Kagel evoked the image of everyday life, the transience of life, the still present social stratification, and the differences in social statuses. He evinced these aspects by relocating the theater from its original environment, while assigning the role to the performers of both, musicians and actors. This is further corroborated with Kagel's words: "When a performer is able to identify with the musical score, with his partthrough this code I have won because my message has arrived right to the performer as well as the audience." "Kagel, who was, like Cage, from the New World, did not feel obliged to deal with the German and European struggles between tradition and innovation. There was just one direction: straight ahead. And, as Henze (Hans Werner Henze) said: 'who knows where 'ahead' is?" (Salzman and Desi 2008, 141)

\section{GEORGES APERGHIS AS COMPOSER OF INSTRUMENTAL THEATRE}

The genre of instrumental theater was also contributed to by the work of the French composer of Greek descent Georges Aperghis. "One of Aperghis' greatest contributions is his founding of the Atelier Thêatre et Musique (ATEM) in 1976. This French ensemble created works of contemporary theater in which the players performed on instruments, sang, danced, and acted." (Fusik 2013,43) The very name of the ensemble, as well as the multiple functionality of the musicians who very often play the role of dancers and actors, indicates an unbroken connection and permeation of different arts. It is precisely the synthesis of music, acting and dance that can be noticed with every actor on the stage, which is real instrumental theater and positions Aperghis, among the other composers, among the members of this genre.

\footnotetext{
${ }^{11} \mathrm{http}: / /$ www.bruceduffie.com/kagel.html, accessed on the 17 th of June
} 
Aperghis rejects the hierarchy of visual versus musical elements in his theatrical works, stating the following: "The visual elements should not be allowed to reinforce or emphasize the music, and the music should not be allowed to underline the narrative. Things must complement themselves; must have different natures. This is an important rule for me: never say the same thing twice [...]. Another thing has to emerge that is neither one nor the other; it is something new." (Fusik 2013, 47)

"Pursuing a need to develop a more liberated, personal language, he gravitated towards the work of John Cage and Mauricio Kagel"12, reflected in the way he conceives various aspects of compositions. Aperghis was concerned with the semantic value of language, its meaning, which made him to explore the limits of the intelligible. By giving importance to each art individually, without forming a hierarchy in terms of the importance of music, theater, or dance, Aperghis places them at the same level, thereby achieving a complete balance between them. Accordingly, "many creations bridge the gap between short plays and operas." 13

Open to new influences and experiments with contemporary trends, the composer combines acting, music and dance with other arts and their various forms, indicating his broad and open understanding, as well as his comprehension of social and scientific (primarily humanistic) fields. This is obvious and constant collaboration with translators, as a logical outcome for Aperghis examining the limits of language expression, while the application of innovations such as electronics, robots, machines, justifies the composer's openness to other sciences and arts or their combinations.

"Referring equally to musicians and actors, his musical works are inspired by everyday life, by social realities transposed into a poetic world that is often absurd and satirically evolving as progress. All segments (vocal, instrumental, gestural, stage) have equal status and contribute to the dramaturgy of these stage works, regardless of any pre-existing text. These pieces often introduce theatrical elements, sometimes of a purely gestural nature, that confirm his concern by performing outside and inside the theater."14

\subsection{Instrumental theatre in Georges Aperghis`Sept crimes de l'amour}

Aperghis' piece, chosen as the analytical sample of this piece, "Sept crimes de l'amour" (Sept crimes de l'amour), was created in 1979 in the spirit of instrumental theater for the movie of Michel Fano (Michel Fano) and was written for soprano, clarinet and percussion." 15 The score shows the position of the three protagonists over seven movements/scenes, arranged sequentially. The unfolding of these seven passionate crimes is rigorously articulated by the music and the positions that the three protagonists must adopt over the seven movements (marked down in the score), which are carefully planned to produce the sounds the composer envisioned. "Apart from the musical score, there is no element of stage directions. The stage design rests on the use of props (some symbolic, such as an apple) and the specific use of instruments (e.g. the body of the clarinet without mouthpiece, etc.) that also contribute to the stage appearance of this theatrical piece."16

\footnotetext{
${ }^{12}$ https://web.archive.org/web/20041216041011/http://www.banffcentre.ca/theatre/history/opera/production_199 6A/biography.asp, accessed on the 19th of June

${ }^{13} \mathrm{http}: / /$ www.lafolia.com/georges-aperghis-and-die-hamletmaschine/, accessed on the 22th of June

14 file:///C:/Users/PC/AppData/Local/Temp/Rar\$EXa8092.38158/Grove/Entries/S01079.htm, accessed on the 18 th of June.

${ }^{15} \mathrm{https} / / /$ ficciondelarazon.org/2016/09/20/georges-aperghis-sept-crimes-de-lamour/, accessed on the 28th of June

${ }^{16}$ http://www.warszawska-jesien.art.pl/en/wj2014/program-i-bilety/work/424074062, accessed on the 25th of June
} 
There are three protagonists of this scene, the clarinetist and the percussionist are male, and the singer is female. She is located between the two instrumentalists, and through her own gestures, movements, and position, she shows dominance over men. This makes the composer portray their inferiority and, tired of the ordinary everyday life that surrounds them, the clarinetist and the percussionist fall under the influence of the singer. Her mimicry, her singing and stretching of the belts, shows her enterprising abilities and creates action on stage. Singing "awakens" and initiates instrumentalists and she engages in a dialogue with them. The singer who uses her belt as a prop is symbolic of the strength which the composer assigned in this scene to the woman. The love triangle set on the stage matches the name of the piece ("Seven crimes of love"), while the singer was showing more affection for the clarinetist.

In the second act, the positions and the roles of the protagonists change. The singer is now also set between the two instrumentalists, but with the role of a medium whose function is to transmit, direct and disseminate sound. Accordingly, she is now subordinate to the instrumentalists. The singer expresses her dissatisfaction with the newly created situation by performing the tones in the high register in the forte dynamics, as well as her mimicry. Her face reflects the sadness and pain caused by the singer's subordinate status in her relation to the instrumentalists.

The specific setting of the protagonists is symbolic and an analogy can be observed with the physiognomy of the human organ - the ear. The clarinetist produces a sound whose vibrations reach the 'darabuka` which the singer holds in reverse so that the open part has the function of a resonating box. It transmits vibrations to the clarinetist-percussionist and prevents them from spreading, but directs and conducts sound to it. The role of the clarinetist-percussionist is to receive and reproduce these vibrations to the audience. This transmission of sound, seen through a view of the auditory organ, suggests that the first clarinetist can be assigned the function of an external ear that collects and conducts sounds. A singer with a reverse 'darabuka` would have the function of a middle ear whose role is to convert vibrational sound waves into mechanical energy. Finally the clarinetist-percussionist might identify with the inner ear, in which vibrations are transformed into electrical signals that, through the nerves, travel to the brain, or to the audience.

In addition to the symbolism observed in this and the previous scene, it can be observed that, in addition to not delineating the roles of musician and actor, Aperghis made sure that the performers knew the possibilities of multiple instruments so that his ideas could be embodied.

In the third scene, the inferiority of the woman is even more pointed out and indicated by her physical position. Hey lying in the instrumentalist's lap can be interpreted in two ways. The singer has the role of a prop because she has the function of a percussive instrument, as indicated by the percussionist's beating on her feet. In addition, the singer is given the role of a resonator as the clarinetist rests his clarinet on her neck while playing, which makes her body become a resonator box of the instrument. The inferiority of the woman is further underlined by the clarinetist procedure as he places the other clarinet without a mouthpiece in the singer's throat. Discrediting a woman is reflected in the singer's recumbent position, her function as a percussive instrument, and discouragement from having the right to speak and her opinion achieved by positioning another clarinet in her throat, despite what she tries to speak. In this way, the woman was literally used as an instrument.

Looking at how the protagonists are organized in the fourth scene, one can see the multilayered symbolism that the composer has designed. The singer, who was facing the 
instrumentalists, with her position and gesture, shows superiority over those who watch her closely. The inferiority of the woman portrayed in the previous scenes has been replaced by her dominance in the fourth. By keeping her score turned to instrumentalists, gesturing and the sounds she produces, the singer also expresses her professorial/conductor features. This is reflected in her attitude, posture, and ordering the instrumentalists to watch and do what she requires. In addition to her position and professorial attitude in relation to the others, Aperghis uses the apple as a symbol found in the singer's mouth. The apple, as a symbol of prosperity, wisdom and harmony, catches the attention of instrumentalists and hypnotizes them, highlighting the dominance of woman even further.

The equality of woman and man is noticeable in scene five and is reflected in the symmetrical setting of the protagonists who form a triangle. A clarinetist, a singer and a percussionist produce the same tone using the reverse-sided 'darabuka'. A clarinetist using a specific clarinet register, a singer performing a glisando which flows into a moan and a percussionist whose scream is muffled with the help of the body of a 'darabuka' have the effect of depicting a person's everyday life and escape from it.

In his piece "On Ugliness", Umberto Eco quotes Nietzsche: "Ugly is understood as a hint and a sign of degeneration... Every sign of exhaustion, sluggishness, senility, fatigue, every kind of loss of freedom, such as spasm and paralysis, and above all smell, color, a form of decay rot... it all evokes the same reaction, a judgment whose meaning is the word ugly... What, then, does a man hate? No doubt: he hates the twilight of his kind." ${ }^{17}$ The production of moaning with the help of voice and instruments in the fifth scene represents "the aesthetics of the ugly, the symbol of the discomfort of the modern man, the moment in which his soul is falling apart, the symbol of mental pain, despair, loneliness, lack of understanding, melancholy, emptiness, and escape from everyday life, people and environment." 18 At the end of the scene, the protagonists' air intake is a symbol of their breathing in relation to the rigors of daily life which leads them to madness.

In the sixth scene, Aperghis took advantage of performers who, working together, build a symbol - a typewriter. The percussionist, centered in a sitting position, simulates writing a text on the instrument, producing a squeaky and shrill sound. At the same time, the singer and the clarinetist, by performing high frequencies, hold one clarinet, which they move simultaneously and at the same time around the percussionist's head. Accordingly, the percussionist reflects the body of a typewriter, while the singer and the clarinetist function as a paper holder. Through the positioning of the clarinet around the head of the percussionist, another kind of symbolism can be observed, the suffocation of man by everyday life and bureaucracy.

The sixth scene builds on the final, seventh scene, which begins with the same role and position of the protagonists, depicting the subordination of man in the existing regime that rules. However, the last scene was formed as a collage of the previous ones. The sixth is followed by the reminiscence of the fourth scene, which continues the exploitation of the man, as the professorial attitude of the woman comes to the fore again. However, as a kind of absurdity and grotesque, the second one is added to the fourth scene, which re-establishes the inferiority of the woman in relation to the previous dominance, which is now in the function of the medium of sound transmission. By doing so, by stacking the scenes on top

\footnotetext{
${ }^{17} \mathrm{http}: / /$ edimagazine.me/teor-estetike-ruznog-film/, accessed on the 21 st of June

${ }^{18} \mathrm{http} / / /$ www.akuzativ.com/teme/226-edvard-munk-vrisak-u-slu\%C5\%BEbi-melanholije, accessed on the 25th of June
} 
of each other within the final scene and reminiscing about them, Aperghis achieves a rounded piece and positions the culmination at the very end of the cycle (see Fig. 3).

In Aperghis' "Seven Crimes of Love", the performers play the role of musicians and actors according to the symbiosis of musical and theatrical art that the composer embodies in his works. The composer paints out the state of society in the existing, ruling regime by using many symbols. This is accomplished by the position of the protagonists, their behavior on stage, the use of props and instruments in an unusual way, thereby obtaining the opposite function from the original one. Aperghis's goal and the message he wants to send to the audience is that, by portraying the social issues, the social system and the position of men and women in the world, he points out the very reasons and crimes that love is suffering today.

Georges Aperghis Les sept crimes de l'amour

Scenes at the cycle level

I scene II scene III scene IV scene V scene VI scene

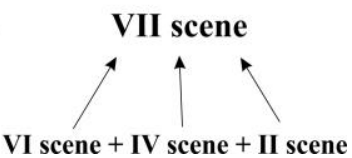

Fig. 3 Arranging the scenes within the final scene, which makes Aperghis in Les sept crimes de l'amour achieves a rounded piece and positions the culmination at the very end of the cycle

\section{HEINER GOEBBELS AS COMPOSER OF INSTRUMENTAL THEATRE}

"I don't consider theater to be an instrument to make statements about reality, I prefer theater as an experience. "19

(Heiner Goebbels)

"Composer and director Heiner Goebbels is one of the most important actors in the contemporary music and theater scene." ${ }^{20}$ His professional commitment has found application in the instrumental theater genre, whereby their symbiosis has been achieved and they cannot be separated. The work of the audience contributes to the formation of Goebbels' compositions as well as the improvisation of the musicians, which makes his works subject to a more free conception. For this reason, "it is not easy to confine him to a strictly defined artistic category, because his work deconstructs the conventions of opera, theater, and concert music., ${ }^{, 1}$

\footnotetext{
${ }^{19} \mathrm{https} / / / \mathrm{www}$. theguardian.com/music/2018/oct/09/from-bombsites-to-usain-bolt-manchester-relives-100-yearsof-war-and-peace, accessed on the 21 st of June

${ }^{20} \mathrm{https} / / / \mathrm{www}$. heinergoebbels.com/en/about/biography, accessed on the 27th of June

${ }^{21} \mathrm{https}: / /$ egs.edu/faculty/heiner-goebbels, accessed on the 27 th of June
} 
Goebbels' works are inspired by certain life situations that are well-formed thanks to the composer's versatility and knowledge of the various arts (music, theater, film) and scientific disciplines (sociology). "In the 1980s, he began to create a series of audio plays as well as staged concerts, all of which took him directly to musical theater as his natural form." (Salzman and Desi 2008, 163)

'In Heiner Goebbels's formulation, the 'staging of a music' ('Composition as a mise-enscène') may be an important or even essential part of the underlying concept" and that is another indication of the composer's endeavor to connect more arts through instrumental theater. (Salzman and Desi 2008, 105) "Goebbels's method is not one of a collage; rather, he aims to find ways in which music can create images by quoting various elements. The eclectic nature of his pieces often prevents audiences from being able to predict the next element in the performance." 22

Goebbels pays more attention to visual elements than any other musician, and inevitably, society plays a key role in drama. He has an active role in all artistic elements, and "his use of the term 'musiktheater' harkens back to the innovations that Wagner (Wilhelm Richard Wagner) had in mind with the 'Gesamtkuntstwerk'.."23 Accordingly, the symbiosis of the various items in Goebbels' compositions, achieved through the influx of different arts, is a logical outcome of the composer's activities and inclinations for diverse artistic fields. Considering all aspects of Goebbels' personality, one can see that after Mauricio Kagel and Georges Aperghis he continued the active development of the instrumental theater genre.

\subsection{Instrumental theatre in Heiner Goebbels`Surrogate}

The piece Surrogate $(2015)^{24}$, written for piano, percussion and soloist, was moved from its original, theatrical environment and positioned in a new context, in a concert hall. The composition begins with the performance of a flickering tone by a percussionist on the basis of which the pianist supplements (see Fig. 4).

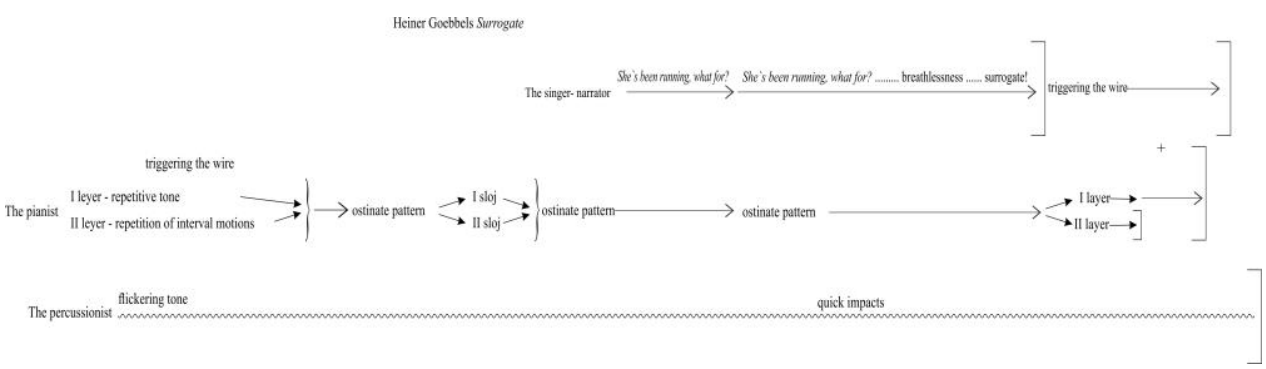

Fig. 4 A graphic representation of the musical-dramaturgical flow in Goebbels's Surrogat

By the direct firing of the piano wire and the continuous repetitiveness of the tone on the piano, the pianist simulates the flickering tone of the precursor, which also receives the function of the ostinate layer. It becomes more complex by the addition of a new layer, whereby these two merge and form a more complex ostinate pattern. However, this more complex pattern is reduced to two ostinate layers, of which it is formed. The first

\footnotetext{
${ }^{22} \mathrm{https} / / /$ egs.edu/faculty/heiner-goebbels, accessed on the 23rd of June

${ }^{23} \mathrm{http}: / / \mathrm{www}$.paristransatlantic.com/magazine/interviews/goebbels.html, accessed on the 18th of June

${ }^{24} \mathrm{https} / / /$ www.heinergoebbels.com/en/archive/works/complete/view/385, accessed on the 16th of June
} 
one is characterized by the repetitiveness of the tone, and the second is characterized by the repetition of interval movements. Their re-synthesis, with the subtle accompaniment of the percussionist, forms a pattern that will serve as the basis for a singer-narrator appearance. The entry of the singer, who plays the role of a narrator of the action, can be followed by the protagonist's mutual communication achieved by subtle glances. All of these signs are of a consensual nature and aim to form an interaction for the best possible interpretation.

She's been running, what for $?^{25}$ is the question that winds up as a thread during composition. The repetitiveness and motility of the pattern, performed by the pianist at a fast tempo, reflects the meaning of the text - the running away by female person, pronounced by the singer-narrator. Performing quick strokes of the percussionist in dialogue with the pianist forms a kind of complementarity in the musical-dramaturgical flow and creates a flickering background, allowing the composer to voice the narrative. The reason of a female person for running away is the subject of research into this composition. Why she runs away in the city during the day? What makes her to look like she's late to the bank or doctor's office? Like she forgot something, was she trapped? A still unresolved question, which is the main motive, the delay motif, is highlighted by a simulation of breathlessness due to the delay evoked by the musician-narrator.

The musical activity of the narrator as a result of this segment of composition comes to the fore as Goebbels accomplishes a symbiosis of music and drama. The tension is intensified in the musical-dramaturgical flow by the simultaneous accompaniment of a percussionist and pianist, based on the repetitiveness of the pattern that creates a minimalist character of the piece. The narrative is further based on the psychological analysis of the run-off woman. It looks like she was cheated, attacked, as if she had just escaped, as if she had lost something, as if she knew something no one else knew, as if she didn't belong here, as if she were unemployed, as if she were a surrogate! The narrator's articulate, expressive and harshly spoken words heighten the tension in the musical-dramaturgical flow, culminating in reaching the end point - by repeating the keyword surrogate! This is underlined by the harsh expression on the narrator's face, which further creates anxiety. Once the culmination point has been reached, the ostinate pattern is simplified by separating the ostinate layers that make up its composition.

The first layer, specific for tone repetition is differentiated from the second, the one which is distinctive for the repetition of interval movements. In the further musicaldramaturgical flow, the second layer disappears and only the initial layer remains. The composer finishes the composition in the way it began, with the repetitive tone and the direct firing of the piano wire by the pianist, which ends the piece and thus achieves its roundness. On the other hand, the motif of constant escape contributes to the creation of a circular form which is constantly flowing and which is formed due to the constant repetition of ostinatical patterns, repetitive tone, but also due to the question of the narrator: She's been running, what for?, which pervades the whole musical-dramaturgical flow.

By repeating the word surrogate at the end of the composition, its importance is emphasized and it is a reason for further interpretations. As surrogate motherhood is a relationship in which one woman presents a pregnancy to a person or couple who then adopts a child, in this way the surrogate mother gives one part of herself to others. This interpretation is reflected through the example of a woman who is constantly running away

\footnotetext{
${ }^{25}$ The singer utters these sentences in the moments of his narration.
} 
in a composition called Surrogate. One part of her is sacrificed to others, to the everyday life that surrounds her, to the work and obligations in life, while on the other side she would escape from everything, from all obligations. For this reason, her hidden part seems frantic, strange, because of her constant pursuit of finding herself in a chaotic time. By various procedures of Goebbels it can be seen that Surrogate is completely imbued with symbolism. The motif of everyday life, the futility of life, the fast-paced, fulfilling way of life pervades Surrogate, which connects this composition with Kagel's Pas de cinq and Aperghis's Sept crimes de l'amour.

\section{CONCLUSION}

Instrumental theater has a tendency to become one of the global trends in the last forty years, as indicated by the fact that composers whose works have been selected as analytical samples for this work have emerged and acted in different environments (Kagel: Argentina, Germany, Aperghis: Greece, France, Goebbels: Germany, Switzerland, whole world). The world feature of the genre itself is further enhanced by the institutions that nurture instrumental theater: Brooklyn Academy of Music (New York, USA), Chant Libres (Canada), Munich Biennale (Germany), Avignon Festival (Avignon, France), Plex (Copenhagen, Denmark), etc.

Looking at the compositions of Mauricio Kagel, Georges Aperghis and Heiner Goebbels, one can see similarities in the way the instrumental theater genre is conceptualized. The different levels of symbolism can be transparent, such as in the case of Kagel who indicates it by the very title of the work "Cinque Pas". In further analytical deepening of the layers of the composition one can see the importance of number five, which the composer evinced by the formation of a space in the form of a pentagon, with the strips entering into its composition being five meters wide. In addition, he hired five protagonists to realize the piece, who participate in the creation of five boundaries in the musical-dramaturgical flow. The rhythmic patterns characteristic for this composition are predetermined for the steps and strokes of the sticks. In his work, Kagel depicts social layers and differences in social statuses that are still present through the protagonists who use the steps and strokes of the sticks for producing sounds that are supposed to be uniformed.

On the other hand, Aperghis emphasizes symbolism in his work by the use of props (apple) and the specific use of instruments (clarinet body without mouthpiece) that contribute to the scenic appearance of this theatrical work, thus also depicting the state of society in the ruling regime. He develops his seven passionate crimes rigorously, as the protagonists have to follow the music and positions which are put down in the score throughout all seven movements in order to produce the sounds the composer envisioned. By portraying the social system, the position of men and women in the world, Aperghis attempts to define some precise reasons for the crimes that afflict love today.

The motif of constant escape is reflected in the composition Surrogate of Heiner Goebbels, which also refers to the symbolism that the composer implements. He depicts the escape of man from everyday life, obligations, constant pursuit of finding himself in a chaotic time. He achieves this by staging a musical-theater piece in a concert hall instead of on the stage.

Kagel, Aperghis and Goebbels, evoke the image of everyday life in society, the still present social stratification, as well as differences in social statuses by various means 
(costumes, unusual use of instruments, etc.). They do this with the help of the protagonists, who play the role of musicians and actors, who comment with the mimicry of their performance and the performance of others. They build up an agreement for further movements and sounds pointing to various aspects of difficulties, satire or confusion. Composers move the theater out of its original environment, which bring the performers closer to the audience with whom they interact with and which influences the formation of the compositions. All the above mentioned elements in the works of Kagel, Aperghis and Goebbels undoubtedly reflect the main and essential characteristics of the instrumental theatre genre.

\section{REFERENCES}

Theoretical studies

Brkljačić, I., (2011), "Istar - instrumentalni teatar. Teorijska studija o istoimenom ciklusu nascentnih muzičkih karikatura za scensko izvođenje u pozorišnom dekoru" ["Istar - instrumental theater. Theoretical study of the eponymous cycle of nascent musical caricatures for stage performance in theatrical decor"], Muzički talas 40, Vol. 17: pp. 2-33.

Fusik, J. P., (2013), The Theatrical Saxophone: Visual and Narrative Elements in Contemporary Saxophone Music, Doctoral dissertation, Bowling Green State University.

Heile, B., (2006), The Music of Mauricio Kagel, Ashgate Publising Limited, Farnham.

Macdonald, H., (2005), The New Grove Dictionary of Music and Musicians, Oxford University Press, London.

Rapajić, S., (2018), Muzičko pozorište kao umetnička sinteza [Musical theater as an artistic synthesis], Fakultet dramskih umetnosti, Beograd.

Salzman, E. and T. Desi, (2008), The New Music Theater. Seeing the Voice, Hearing the Body, Oxford University Press, Oxford.

Šuković, M., (2018), "Uodnošavanje muzičkog, dramskog i scenskog teksta u instrumentalnom teatru Istar Ivana Brkljačića" ["Reconciliation of musical, dramatic and stage text in the instrumental theater Istar by Ivan Brkljačić"], u: Radost Galonja Krtinić (ur.), Kozara kroz riječ, zvuk i sliku: zbornik radova iz oblasti humanističkih nauka, Grafopapir, Banja Luka: pp. 99-113.

Other Sources - Accessed on June 15-30, 2019.

http://www.bruceduffie.com/kagel.html

https://www.nytimes.com/2008/09/20/arts/music/20kagel.html?_r=1\&oref=slogn

https://www.theguardian.com/music/2008/sep/19/obituary.mauricio.kagel?gusrc=rss\&feed=music

http://www.washingtonpost.com/wpdyn/content/article/2008/09/19/AR2008091903900_2.html?noredirect=on

http://www.beckmesser.de/neue_musik/kagel/int-e.html

https://web.archive.org/web/20041210161741/http://www.edition-peters.com/kagel/

http://www.ubu.com/film/kagel.html

http://www.bbc.co.uk/radio3/cutandsplice/kagel.shtml

https://musicterms.artopium.com/c/Cinquepas.htm

file:///C:/Users/PC/AppData/Local/Temp/Rar\$EXa8092.38158/Grove/Entries/S01079.htm

https://www.vichoyland.org/Productions/Pas-de-Cinq-by-Kagel-153

https://genovaquotidiana.com/2016/04/04/la-claque-da-john-cage-a-mauricio-kagel-quando-la-musica-

diventa-teatro-mercoledi-ultimo-appuntamento-de-le-strade-del-suono/

http://www.magazzini-sonori.it/esplora/compositori/kagel_mauricio.aspx

http://www.warszawska-jesien.art.pl/en/wj2014/program-i-bilety/work/424074062

https://ficciondelarazon.org/2016/09/20/georges-aperghis-sept-crimes-de-lamour/

https://en.wikipedia.org/wiki/Georges_Aperghis

http://www.aperghis.com/biographies.html

https://web.archive.org/web/20041216041011/http://www.banffcentre.ca/theatre/history/opera/production_1

996A/biography.asp

http://www.lafolia.com/georges-aperghis-and-die-hamletmaschine/ 
http://www.lafolia.com/even-further-aperghis-sightings/ http://www.ubu.com/sound/aperghis.html https://www.heinergoebbels.com/en/about/biography https://www.boosey.com/composer/Heiner+Goebbels https://en.wikipedia.org/wiki/Heiner_Goebbels\#cite_note-egs-2

https://web.archive.org/web/20101227073108/http://www.ruhrtriennale.de/en/presse/pressemitteilungen/pre ssemitteilung-24-09-10/

https://www.theguardian.com/music/2018/oct/09/from-bombsites-to-usain-bolt-manchester-relives 100-years-of-war-and-peace

http://www.paristransatlantic.com/magazine/interviews/goebbels.html

https://egs.edu/faculty/heiner-goebbels

http://www.cdmc.asso.fr/en/actualites/saison-cdmc/mauricio-kagel-and-instrumental-theatre

https://www.heinergoebbels.com/en/archive/works/complete/view/385

https://www.youtube.com/watch?v=-BqZILDP95E\&t=6s

https://www.youtube.com/watch?v=aZ48kO_LiRs

https://www.youtube.com/watch?v=6ctbfxlLhpQ

\section{INSTRUMENTALNI TEATAR U KOMPOZICIJAMA MAURCIJA KAGELA, ŽORŽA APERGISA I HAJNERA GEBELSA}

Karakterističnost žanra instrumentalnog teatra ogleda se u simbiozi muzičke i pozorišne umetnosti, kao i u tome što su kompozitori istovremeno i režiseri, dok muzičari imaju mogućnost da, pored svojih očekivanih uloga, budu u kontaktu i sa ostalim umetnostima. Specifika žanra je njegovo izmeštanje iz prvobitnog okruženja i smeštanje u novi kontekst, čime su izvođači u međusobnoj interakciji, ali $i$ u bliskoj komunikaciji sa publikom. Uticaj publike na izvođenje ima veliki udeo u konačnom oblikovanju dela zbog čega je njen angažman od izuzetne važnosti za ovaj žanr. Žanru instrumentalnog teatra najveći doprinos dali su kompozitori Mauricio Kagel, Žorž Apergis i Hajner Gebels.

Ključne reči: instrumentalni teatar, Mauricio Kagel, Žorž Apergis, Hajner Gebels, simbioza 